\title{
Protein Synthesis Inhibitor
}

National Cancer Institute

\section{Source}

National Cancer Institute. Protein Synthesis Inhibitor. NCI Thesaurus. Code C784.

A pharmacological agent that inhibits the protein translation process. Protein synthesis inhibitors may be used therapeutically as antibacterial or bacteriostatic agents. 